\title{
Relacionamento entre os controles internos e externos da Polícia Militar do Distrito Federal
}

Christyne Carvalho da Silva

Curso: Mestrado em Sociologia

Data da defesa: 3 de julho de 2008

Orientador: Prof. Dr. Arthur Trindade Maranhão Costa

\section{Resumo}

Este trabalho sociológico trata do relacionamento entre os controles interno e externo exercidos sobre a Polícia Militar do Distrito Federal (PMDF). O controle é feito por meio de ouvidorias, 
da Corregedoria da polícia, dos entes do Legislativo, Executivo, Judiciário, além do Ministério Público e de um órgão de classe de maior visibilidade à matéria. Cabe ressaltar que esses não são os únicos meios de acesso ao controle da PMDF, mas despontam em nível distrital como os mais influentes.

Pretendeu-se conhecer de que modo os órgãos de controle interno e externo da PMDF foram criados, identificar como os mesmos órgãos de controle interno e externo funcionam, o corpo burocrático, a legislação específica, a vinculação e o processamento dos casos chegados até eles; avaliar a adequação da execução das medidas de funcionamento daqueles órgãos aos objetivos propostos durante a criação dos mesmos; e entender se essas modalidades de accountability da PMDF conseguem ser instrumentos de confiança, de acordo com o que se reflete na literatura específica existente.

De forma geral, poder-se-ia dizer que é um sistema do tipo centralizador na figura da Corregedoria, e isso porque nenhum dos agentes é capaz de agir sem que o parecer do corregedor dê a instrução do caso. É possível verificar que todas as demais instituições de controle têm algum papel fiscalizador e/ou cooperador, embora não exerçam posturas de destaque - exceção feita quando dos casos mais apelativos, em que todos desejam ser partícipes de uma história de impacto.

Palavras-chave: controle interno; controle externo; Polícia Militar do Distrito Federal. 